\title{
Solidarity in Globalisation: When "I's" Live as "We"
}

\author{
MAYBELLE MARIE O. PADUA \\ Far Eastern University, \\ Nicanor Reyes, Sr., Avenue Metro Manila, Philippines 1008 \\ mpmaybellepadua@gmail.com
}

Published online: 15 October 2016

To cite this article: Padua, M. M. O. 2016. Solidarity in globalisation: When "I's" live as "we." KEMANUSIAAN the Asian Journal of Humanities 23(2): 89-117, http://dx.doi.org/10.21315/ kajh2016.23.2.6

To link to this article: http://dx.doi.org/10.21315/kajh2016.23.2.6

\begin{abstract}
This paper explores the theme of community and its connection with solidarity. In an age of globalisation that tends to socio-economic development alone, Edith Stein's theory of community brings to the fore the relational character of our being persons who live with others. Stein's concept of community points to the experience of being and living with others in a way that helps us "promote a person-based and community-oriented process of world-wide integration that is open to transcendence," a project that Benedict XVI proposes in Caritas in Veritate. While many theories on community stress collectivism and the common good as being above the individual person, Stein's theory of community helps us regard both the individual person and community as central to achieving solidarity.
\end{abstract}

Keywords and phrases: Community, solidarity, empathy, spirit, experience, consciousness

\section{Introduction}

"Solidarity" and "community" are concepts that call for philosophical reflection. Both concepts are connected genetically and semantically. While the semantic connection between solidarity and the community is obvious enough, the genetic connections are not and thus needs investigation. Both terms - solidarity and community - belong to the language of values and are appreciated from the standpoint of "connectedness."

This link to oneness can be said to be embedded in our natural connection as human beings. The fact is, even before we are born, we are already in the

(C) Penerbit Universiti Sains Malaysia, 2016 
company another human being, in the womb of the woman who bore us. The condition of the unborn child already shows the necessity of relationships from the moment the child is conceived. As Ratzinger elucidates it in Introduction to Christianity, "the being of another person is so clearly interwoven with the being of this first person, the mother, that for the moment it can only exist at all in bodily association with the mother $(2004 a, 246)$. Except under unusual circumstances, one's first natural community is the family, making the family even older than the State (Leo XIII, 1891, 12). From the family, other communities develop: one's political society, one's village, one's tribe. We see that upon being born, we are already dependent on others. Our "being," so to speak, is immediately connected to others. It is neither solitary nor detached from the existence of other human beings. That is because it belongs to human nature to come into existence and to continue that existence with other humans, to "be with" them. Precisely because of this condition as human, a person has to "be with" others, has to "live in relation with" them. It is his ontological peculiarity to do so.

Thus understood, the fact of persons being and living with others is not an invention of human ingenuity (as in the political teachings of modern social contract theorists) nor an artificial construction designed to make up for human nature's shortcomings. It is, rather, a prompting of nature itself that sets humans apart from all other natural creatures. To be sure, to be in association with other human beings, is not simply given by nature. It is rather something to which human beings naturally aspire and which is necessary for the full perfection of their existence. Given the human persons' essentially spiritual nature, persons are by nature capable of the experience of common values that make them "live together" and not just survive or co-exist. This human "living with" each other is best expressed by the terms "solidarity" and "community" or the philosophical notion of the experience of common values that describes the existential idea of human wholeness. It is this notion that this study investigates.

The experience of community and its profound meaning is described by Edith Stein $^{1}$ (1891-1942) in her treatise Individual and Community. ${ }^{2}$ Stein is the first philosopher to give an account of a phenomenology of the experience of community and a phenomenological description for the ontic structure of the community (Calcagno 2007, 26). ${ }^{3}$ Stein maintains that the experience of community is marked by one living in the experience of the other. "The community becomes conscious of itself only in us" (Stein 2000,139). Solidarity exists insofar as members of the community responsibly share in the lives of one another (Stein 2000,130, 195). Characteristic of community, in its purest form, is the reciprocal openness of one individual to the other (Stein 2000, 201-203). 
On the other hand, the idea of solidarity as an achievable goal for the world to be one human global community is taken up by Benedict XVI (1927 to present) in his encyclical Caritas in Veritate (henceforth CV) (Benedict XVI 2009). Benedict's vision of solidarity is one of anthropological unification of all human beings into one single human family: a community of fraternity that is realisable because we have one father, God. Benedict thinks this is not a far-fetched idea in human terms, especially as humanity is becoming more and more interconnected in today's modern age of technology. Borders have diminished. Distances have minimised. The intensification of consciousness of the world as a single whole has acquired new significance in today's globalised times: the world today is one characterised by greater interdependence and increased interaction in a single time-zone in which everyone is in real-time communication with everyone else. Yet, Benedict XVI observes that in many ways, we have become neighbours, but we have not become brothers (Benedict XVI 2009, 19).

In $C V$, Benedict introduces a new motive that goes beyond justice for building the world: charity and love. In $C V$, Benedict proposes to appropriate the underlying anthropological and ethical spirit that drives globalisation towards humanizing solidarity to make it person-based and community-oriented.

In this essay, I attempt to correlate Benedict XVI's proposals in $C V$ with the philosophy of community of Edith Stein who came a century ahead in laying down the ideals for achieving solidarity. Stein draws a phenomenological framework of being with and living in relation with others which is useful to give flesh to the otherwise abstract ideas that we find in $C V$. In what follows, I try to connect what I call Benedict XVI's solidarity project in $C V$ with Edith Stein's philosophical theory of community in the hope of finding phenomenological solutions to the anthropological and ethical problems raised in $C V$.

\section{The Solidarity Vision of Benedict XVI in CV}

Authentic and integral development flows from recognising what the human person is. $C V$ proposes an authentic human development that is consistent with the integral vision of man. The Pope notes that "the social question has become a radically anthropological question" (Benedict XVI 2009, 75). This calls for looking into the meaning of authentic development and on what is integrally human and development is not authentic and integral if it is merely technical or utilitarian. Indeed, development, properly understood, is not limited to material existence. "True development does not consist primarily in "doing" (Benedict XVI 2009, 70) that is, in mere physical accomplishment. Development is not just "a matter of financial engineering, the freeing up of markets, the removal of tariffs, investment in production, and institutional reforms - in other words, a 
purely technical matter" (Benedict XVI 2009, 71). True development is one that considers man in his integrality or completeness, a being with body, soul, a being that exists and lives in relation with others, starting with God. True development regards the human person as fundamentally ordered to relations and not simply as autonomous individual.

For Benedict, as for Stein, the relational nature of human persons has its roots in a cry for the "You" to fill in man's solitariness in his "I."

Where men have experienced existence in its fullness, its wealth, its beauty, and its greatness, they have always become aware that this existence is an existence for which they owe thanks; that precisely in its brightness and greatness it is not what I myself have obtained but the bestowed that comes to meet me, welcomes me with all its goodness before I have done anything, and thus requires of me that I give a meaning to such riches and thereby receive a meaning. On the other hand, man's poverty has also acted again and again as a pointer to the entirely Other (Ratzinger 2004a: 105).

Indeed, being a man means being a "fellow man" in every aspect (Ratzinger 2004a: 247). We learn from Ratzinger that to be a human person is to be fundamentally relational. The human capacity for communion with God and with other human persons ties in closely to the meaning of personhood as such. It brings with it the call to love.

Love (referring to the love of God) is derived from the original Greek agape which means selfless love. ${ }^{5}$ Agape is used by Christians to express the unconditional love of God for us. This type of love was explained by Thomas Aquinas as "to will the good of another."6 Agape is used in the biblical passage known as the "love chapter," 1 Corinthians 13, and is described there and throughout the New Testament as sacrificial and spiritual love. Whether the love given is returned or not, the person continues to love (even without any selfbenefit). This was a love that you extended to all people, whether family members or distant strangers. Agape is also used in ancient texts to denote feelings for one's children and the feelings for a spouse, and it was also used to refer to a love feast. It can also be described as the feeling of being content or holding one in high regard. Agape was later translated into Latin as caritas, which is the origin of our word "charity."

Only in light of man's nature as destined for fulfilment in love, as Benedict XVI proposes, will this development be realised. In this way, it will be possible to experience and to steer the globalization of humanity in relational terms, in terms of communion and sharing of goods (Benedict XVI 2009, 42). I argue in this 
paper that this goal can be achieved if we understand a person's capacity for living in "community" with others. Edith Stein's concept of community, for me, elucidates what the experience (and not just the abstract idealism) of living in solidarity with others is.

\section{"Community" in the Philosophy of Edith Stein}

Stein describes "community" in an analogous way using the human person as basis for unravelling the ontology of community or what it means to be a community. She likens community to an individual person, a being with personality, character, with a certain genetic constitution, and developing in a particular way.

In her treatise Individual and Community, ${ }^{7}$ Edith Stein refers to community as a "living through" of the experience of one in the other in solidarity. "In community, solidarity prevails," writes Stein (Stein 2000, 130). Community is a category of life marked out by reciprocity between community members.

Where a subject accepts the other as subject ${ }^{8}$ and does not confront him but rather lives with him and is determined by the stirrings of life, they are forming a community with one another (Stein 2000, 130).

The position of Edith Stein on community is of interest because she approaches the notion of community from a phenomenological standpoint, not from a simply theoretical perspective of how things should be. She asks the following questions in this regard: What role does life power play in the total composition of the community? What constituents does the community exhibit, apart from life power? What is the relationship of individual and community (Stein 2000, 198)?

To answer these questions, Stein takes off from two perspectives in her treatment of community: the ontological viewpoint and the viewpoint of consciousness. Stein describes what an experience of community looks like in consciousness, that is, how we experience it phenomenologically. Then she describes the ontic essence (being or nature) of community which is the object of consciousness. Note what she writes:

Communities confront us as realities in our environment: families, nations, religious communities, and so forth. In everyday life we catch sight of them only now and then. For the most part, we're "oriented" to individual persons, and so we're inclined to ascribe to their idiosyncrasy whatever identifies them as members of a community: their social position and the life. 
Indeed, we the lone [community member] along with what accrues to him or her "because of the community," but we don't see the community that's standing behind him or her (Stein 2000, 196).

While Stein draws our attention to the fact that we can overlook the community of which each individual is a part, in her investigation of community, Stein's starting point is the human person. To understand community, it is necessary to have a clear concept of human person. Stein refers to the human person as a spiritual subject constituted as a psycho-physical individual. In her book On the Problem of Empathy (1989), Stein writes that as a spiritual subject, the human person is:

...an "I" in whose acts an object world is constituted and which itself creates objects by reason of its will. If we consider the fact that not every subject sees the world from the same "side" or has it given in the same succession of appearances, but that everyone has his peculiar "Weltanshauung"... (Stein 1989, 96).

Being a spiritual subject, a human person is not just constituted of a body, but of a soul to which we attribute the person's spiritual capacities which include willing, giving meanings to objects, being motivated, and being influenced. Thus, to understand persons, their specific worldviews ("Weltanshauung"), and possibilities for building the world into one community, calls for understanding what goes on in his consciousness (if we are to comprehend what is meant by the spiritual and moral significance of "autonomy"). Stein writes:

Because in order to come close to someone else's inwardness as is necessary for his purpose, you've got to give yourself over to it. You can't make a subject into an object without first having accepted it once simply as a subject (Stein 2000, 131).

How does a person then become conscious of something and of persons specifically? Stein explains how empathy accounts for our awareness of other persons. Empathy is the perceptual consciousness in which foreign persons come to givenness for us (Stein 1989, 96). This explains how persons find meaning or value in something through other persons.

Empathy as the act of an individual consciousness shows how an ego becomes more aware of itself by its understanding of others. Stein uses the term Einfuhlung (German for in-feeling; the translation empathy from em: in, and pathein: to feel is the closest in English) to describe the act of consciousness that 
permits consciousness to know or become inwardly aware of foreign or other consciousness. Einfuhlung thus is an act of consciousness that allows the ego to recognise the other ego as another ego and to understand, in part, the consciousness of the other qua its activity and content; yet the consciousness of the ego is not reducible to the consciousness of the other and vice versa. The ego literally "enters into" (ein) the life of the alter ego, without having to know or understand the consciousness of the other absolutely. If empathy accounts for the natural capacity human beings have for intersubjective relations with others, then solidarity is achievable among all humans regardless of race, culture, or individual differences.

Stein describes empathy as a clear awareness of another person, not simply of the content of his experience, but of his experience of that content. In empathy, one takes the place of the other without becoming strictly identical to him. It is not just understanding the experiences of the other, but taking them on as one's own. Empathy comes from the Greek words im (in) and pathe (meaning to suffer, feel). Stein actually used the German Einfuhlung meaning: "in-feeling" or feeling-into and feeling-within. For Stein, beings are "felt-into." And the meaning derived in feeling through persons is detected in experiences and happens on the level of the spiritual in the person.

The experiential 'meaning context,' so strangely excepted in the midst of psychic and psycho-physical causal relationships and without parallel in physical nature, is completely attributable to spirit... The experiential context of spiritual subjects is an experienced (primordially or emphatically) totality of meaning and intelligible as such. Precisely this meaningful proceeding distinguishes motivation from psychic causality as well as empathic understanding of spiritual contexts for empathic comprehension of psychic contexts (Stein 1989, 96-97).

When the same meanings are attached to an experience (as a mental phenomenon), for the meanings to be known as something shared or common to a number of persons requires an inter-personal matrix, says Stein. That matrix is the community. Stein writes, "...any community unites a plurality of subjects within itself, and is itself a carrier of one life that realizes itself by means of those subjects" (Stein 2000, 197).

Sensations, sensibilities, and emotions resonate across each other. But being a sentient phenomenon, they require an infra-personal matrix: the embodied psyche. For the meanings to be shared, community and psyche need one another for transfer of energy between the individual and the community. 
"...the community is provided with a life power out of which its experiencing is fed; and that the individual makes contributions to this power source and are fed out of it, but need not live with all the power standing at their disposal as members of the community.

A sense-bound world unfolds for the community within its experiencing" (Stein 2000, 197). When I am joyful, I can contribute to the joyful power or sentiment of a community. This joy comes from my smiles, my laughter, my good humour, and in this way I contribute to the joy of other individuals who are members of the same community. In that I communicate my joy in sentient expressions, the community experience of joy is sense-bound; laughing can be infectious, so a whole community life (e.g., in a family) can be always filled with laughter, or smiling people, of persons telling jokes, and making light out of serious things and not putting people down.

This can happen because a community "unites a plurality of subjects within itself, and is itself a carrier of one life that realises itself by means of those subjects. Furthermore we know that the community is provided with a lifepower out of which its experiencing is fed; and that the individuals make contributions to this power source and are fed out of it... (Stein 2000, 197). This shows how important it is for the individuals to remember they have an impact on the life of a community, that they could uplift the spirits of other members or drag it down.

Stein describes how a person can have a consciousness of another person. In phenomenological language, she details how the spirit creeps into the consciousness of the psycho-physical individual.

All perception is carried out in spiritual acts. Similarly, in every literal act of empathy, i.e., in every comprehension of an act of feeling, we have already penetrated into the realm of the spirit. For as physical nature is constituted in perceptual acts, so a new object realm is constituted in feeling (Stein 1989, 92).

For example when I encounter others in the university where I teach, that I come to be aware of them happen as a spiritual act. But their presence affects me as I encounter them physically as Stein describes it: encountering others spiritually happens with experiencing them corporeally. We come to the spiritual person through the psycho-physical individual, encountering them in "the sensually perceivable expression in countenances, etc. or in actions" (Stein 1989, 117). 
In this regard, the physical stance of others can have an effect on me. As their physical stance expresses their moods, feelings, or values, then I can also be affected by those same moods, feelings or values.

This is the world of values. In joy, the subject has something joyous facing him, in fright, something frightening, in fear, something threatening. Even moods have their objective correlate. For him who is cheerful, the world is bathed in a rosy glow; for him who is depressed, bathed in black. And all this is co-given with acts of feeling as belonging to them. It is primarily appearances of expression that grant us access to these experiences. As we consider expressions to be proceeding from experiences, we have the spirit here simultaneously reaching into the physical world, the spirit "becoming visible" in the living body. This is made possible by the psychic reality of acts as experiences of a psycho-physical individual, and it involves an effect on physical nature (Stein 1989, 92).

This, to me, explains how it is possible to infect others with our own joy, or with our sadness, for that matter. And this is what can build a community of persons sharing the same values. Feelings of euphoria can be transmitted; feelings of hope, of patriotism; and certainly feeling of discouragement and pessimism as well. Thus it is important to have positive dispositions and positive feelings for that matter.

Stein clarifies how feelings are object-directed if they are to be referred to as an experience. What is an experience?

Experience refers to a "deeply penetrating" happening within the person. Stein writes, in "theoretical acts," such as acts of perception, imagination, relating or deductive thinking, etc., I am turned to an object in such a way that the "I" and the acts are not there at all. There is always the possibility of throwing a reflecting glance on these, since they are always accomplished and ready for perception. But is it equally possible for this not to happen, for the "I" to be entirely absorbed in considering the object? It is possible to conceive of a subject only living in theoretical acts having an object world facing it without ever becoming aware of itself and its consciousness, without "being there" for itself. But this is no longer possible as soon as this subject not only perceives, thinks, etc., but also feels. For as it 
feels it not only experiences objects, but it itself. It experiences emotions as coming from the depths of its 'I' (Stein 1989, 98).

Stein's example is the feeling of cheerfulness as announcing the personal attribute of cheerfulness to a person which we subscribe to his entire person, not just to a localised portion of his "I," (for example, to his smile alone). We attribute cheerfulness to the whole person, like a "total illumination" of his personality, something that bathes his entire character (Stein 1989, 100).

Through reciprocal relationships, similar attributes and dispositions evolve, together with similar interests and goals, binding the community members in solidarity with each other, in a specific fashion (Stein 2000, 240). It helps to note that the community is not founded or produced by an act of free will like that of a society, which is convened or disbanded at will. Neither is it a sentient structure that affects our psyche, that is, a psychological feeling that we react to as in a behaviorist model, or a social contract in which we tacitly consent to participate. Community is being with the others and "living through" the experience of being with the others in solidarity. This makes Stein's description of community distinct from others, and introduces a profound philosophical shift in political thinking about community.

\section{Solidarity: One Human Race, One Family}

Solidarity can be understood as an attitude of people toward one another, of a single individual towards a group, community or other collective. Solidarity as an attitude involves two components - a cognitive and an emotional one. The genesis of the term "solidarity" yields the Greek ekklesia (church) which Christians used to express the community of the living and the dead united in Christ. Communities of values was used for the Christian vision of social life (Karlowicz 2002, 144).

The need to use the word "solidarity" in order to describe attitudes came in the 19th century. In France, the adherents of de-Christianisation and of the secularisation of morality chose solidarity as the successor to Christian love. Christian love, they argued, is a waste of moral energy as it is divided between God and one's neighbours. It was marked, they claimed, with egoism and bigotry. Already Kant imputed self-interest to people who did good for the sake of eternal reward. On the other hand, Comte, proposed a new altruism of loving others "more than oneself," loving others for their own sake, not for God's. He did not quite agree with the solidarity of Christianity of loving others "as you love yourself" (Salij 2000, 86). 
Later, "solidarity" referred to social awareness and helping the poor, while promoting the common good. The foundation of this understanding of solidarity is formed by the Greek idea of the common good (Christianised by Aquinas in light of the commandment to love one's neighbour) as well as by Christian teachings on the human person. This twofold foundation protects the balance between the interests of an individual and those of the community, which is so difficult to achieve. For, on the one hand, it is a person-someone destined for eternal life and as such irreducible to his social functions - who is the aim of the community, and not the other way around, so it cannot happen that the good of the community ever justifies trampling on the good of any of its members (Salij 2000, 87-88).

Solidarity, according to John Paul II, "is a firm and persevering determination to commit oneself to the common good, that is to say, to the good of all and of each individual, because we are all really responsible for all." Thus, John Paul II claims that with "the growing awareness of interdependence among individuals and nations" solidarity acquires a moral connotation (John Paul II 1987, 38). We cannot be indifferent to others no matter how distant some countries are geographically.

In $C V$, Benedict XVI speaks of a human solidarity that is not just social cohesion, but a recognition of the human race as a single family. The task of solidarity that he proposes asks us to appropriate the underlying anthropological and ethical spirit that drives globalisation towards the humanising of solidarity so that it is person-based and community-oriented. In brief, $C V$ proposes an authentic human development that is consistent with the integral vision of man. The "social question has become a radically anthropological question" (Benedict XVI 2009, 75). Solidarity is seeing the other as our "brother." It asks for a willingness to give, not just to share. Solidarity, is above all, a recognition of the human race as a single family, because we have one father, God (Benedict XVI 2009, 53).

\section{Lifepower and Community}

We might liken solidarity to a value that strengthens the lifepower of a community. Stein writes that there is a correlation between the lifepower of an individual and the community. The more strength the lifepower of an individual has, the greater the lifepower of the community. Stein explains, "The more full of power an individual is, the more abilities he can bring to development and the further each single ability can be increased..." (Stein 2000, 198). To understand this further, we must look into the community's lifepower and its sources. 
In a sense, a community is what it is as a result of the individual members' "mental doing" in Stein's terms (Stein 2000, 197). What the individual conceives that community to be is what the community is going to become. As Stein says, a community unites a plurality of subjects within itself, and is itself a carrier of one life that realises itself by means of those subjects. Furthermore the community is provided with a lifepower out of which its experiencing is fed (Stein 2000, 197).

Stein takes up four components of community life that we need to discuss to understand the lifepower of community. These components are: (a) lifepower as a property of community; (b) the lifepower of individuals as a source for the lifepower of their community; (c) outsiders as power sources for the community: indirect impacts; and (d) the significance of social attitudes for the lifepower of the community.

\section{(a) Lifepower as a property of community}

The life-unity of community as analogous to that of human personality, Stein shows that community can, in a sense, be said to have character, a soul, and a spirit (Stein 2000, 222 ff. entitled Sentient Abilities and the Community's Character). The formation of the character of a community depends on how deeply the community is anchored in the individuals and how the individuals regard the community. The more deeply the community is anchored in its members, the higher the value it possesses for them, and the more it is grounded in their positive dispositions and the satisfaction of inner drives, the more community life grows and develops into a kind of collective personality which lives in and through the individuals.

Genuine community aims at union, a community that is rooted in the personal Umwelt (life world) and touches the core of the personality of the subjects. It is characterised by genuine feelings arising from the personal "I" of each. Person and value world are completely correlated. It is impossible to formulate a doctrine of the person... without a value doctrine... (Stein 1989, 108). We see that the genuine being of community has its origin in the personal individuality of the individuals.

Certainly community involves a spiritual connection among individuals; that is, community exists on the level of Geist ${ }^{9}$ (spirit or life force). Stein refers to an inner energy of the community as "lifepower." Like the person, community has a life force upon which it depends for the vigour and quality of its life. The lifeforce of a community is built up from the life-forces of the individuals. Certainly, individuals hold back certain resources for themselves, but on the whole, the quality of a community's life depends upon the life-giving motives of individuals 
and the vitality with which they carry these motives into action for the life of the community (Stein 2000, 180-185). Stein writes:

There are times of an overwhelming abundance of power, which expresses itself in a multiform zest for action) so that there could be very different kinds of activation at the same height of lifepower, depending on the original predispositions and the external circumstances). And there are periods of exhaustion in which all activeness falters and the nation seems to be "slumbering"... Every stirring of life costs an expenditure of power, and every time there's any great exertion, it's followed by a slackening, a subsiding of power. But the slackening need not absolutely portend nay definitive decline; rather it can set in during the ascent toward the summit, which is made possible by a new influx from the sources of lifepower (Stein 2000, 201202).

In this regard, we see that personal attitudes are significant to the life of a community. It follows that solidarity will come from an attitude of mutual openness to be one and build community life toward this goal. This happens when the individuals are open to one another, when they make reciprocity possible. The attitudes of the individuals toward the community to which they belong are very important. The energy of a country grows when its citizens love it and weakens when some among them hate it. New impulse-forms are brought to community life through positive dispositions and hindered by negative ones. Stein uses the metaphor "life streams." When the life streams of persons flow together, then the persons are united in one stream moving in the same direction (Stein 2000, 202).

\section{(b) The lifepower of individuals as a source for the lifepower of their community}

"The community is 'founded' essentially in individuals" (Stein 2000, 238). The lifepower of a community, does not, according to Stein, exist independently and alongside of its components, but rather coalesces from the power of the single [members] (Stein 2000, 203). For Stein, the person himself or herself is locus and ground of community. The community is founded on individual persons (Stein 2000, 238). Each individual person consists of a living body, a psyche, and a spirit and thus community life is constituted by material as well as psychospiritual phenomena, such as the exchange of feelings, ideas, sentiments, values, and influences on each other. 
Stein is acutely aware of the need for an account of how one person is individuated and thus different from another person. She identifies the personality core as an individuating principle that explains why persons each have a unique character or personality.

The personality core is defined as that ontic reality (reality at the level of one's "being") or locus where the uniqueness of each person is centred or housed. Each personality core is an expression of and is proper to that person. Though we are individuals and though we also experience living in a community, the personality core is what distinguishes us concretely from others and renders us unique unto ourselves. Yet it not only colours the character of the individual (that is an individual who is similar to other persons), but also colours the character of a community.

Though the person has an egological sphere that is his or her own, the individual also finds himself or herself in relationship with others in the world (Stein 2000, 239). The world is given in such a way that we are intersubjectively constituted. The world and the "patrimony" of communal experiences contained therein are foundational for our individual and communal personalities (Stein 2000, 239). In fact, intersubjectivity, as brought to full consciousness in the act of empathy, reveals who we are and who we are not, what I know and what I do not know. I know that I am not the other and I know that my thinking is not identical to that of the other; however, I share with the other many analogous and similar traits and characteristics, and a similar live-body, psyche (sentience), and personospiritual structure, including the pure ego.

To be person is to recognise that there is no such thing as an individual who is completely separated from other individuals. Stein and Ratzinger concur on this point.

"Indeed, being a man means being a 'fellow man' in every aspect," writes Ratzinger (Ratzinger 2004a: 247). We learn from Ratzinger that to be a human person is to be fundamentally relational. The human capacity for communion with God and with other human persons ties in closely to the meaning of personhood as such. This stems from the human person's ontological status of being imago Dei (image of God).

In Communion and Stewardship (Ratzinger 2004b), ${ }^{10}$ we read that imago Dei is the basis for two foundational thoughts about the human person: one, is that the whole of man is created in the image of God and two, that man was not made to be an individual to live in isolation. 
First, the whole of man, and not just parts of him, e.g., the intellect or his upright stature, is created in the image of God. This perspective presents the human being in which the spiritual is understood to be a dimension together with the physical, social and historical dimensions of man (Ratzinger 2004b, 9). The imago Dei is not a locus of human nature in a specific quality or functions, (for example, man's sexual nature or man's domination of the earth). The whole human person is the image of God.

Second, the human person was created to have a relational character and not to be alone. This is laid down by the genesis account, "God created mankind in his image, in the image of God he created them, male and female he created them" (Genesis 1: 27). God placed the first human beings in relation to one another, each with a partner of the other sex. In Communion and Stewardship, we read that "man exists in relation with other persons, with God, with the world, and with himself. According to this conception, man is not an isolated individual but a person - an essentially relational being" (Ratzinger 2004b, 10). This conception explains the fundamentally relational character of the human person as constituting the human person's ontological structure and the basis for its exercise of freedom and responsibility.

For Edith Stein, the relational character of human persons means three things. First, human beings are social and are dependent on others in order to survive as individuals, like children in need of their mothers. Our mutual dependence on one another means that we are not abstract realities nor pure egos stripped of a social nature. Second, in a theological sense, (as advanced in Stein's last book Finite and Eternal Being) just as the Trinity is a relation of three persons in one God, we too are analogously stamped with this image of God in and through our creation and the incarnation of Christ. The intimacy of the life of the three persons means that when we interact with God, we interact with these three persons, who are distinct but related to one another. Moreover, the intimacy of their communal life serves as a model community that we can draw upon to form love communities in our earthly existence. Finally, and phenomenologically speaking, I am constituted as a person only insofar as I am shown to be a person through my understanding of other persons in empathy. The experience of other persons and my consciousness of them make me aware of who I am. Thus, a person's character can be developed through empathy and also influenced by one's psycho-physical world.

Stein speaks about life circumstances of a person as contributory to forming his or her personality, character, and choices. And a man's entire life can be an entire process of the unfolding of his personality. But Stein cautions that it is also possible that psycho-physical development does not permit a complete unfolding, 
and in fact, in different ways. A defective unfolding is also possible. Her own example is:

He who never meets a person worthy of love or hate can never experience the depths in which love or hate are rooted. To him who has never seen a work of art nor gone beyond the walls of the city may perhaps forever be closed to the enjoyment of nature and art together with his susceptibility for this enjoyment. Such an "incomplete" person is similar to an unfinished sketch (Stein $1989,111)$.

To my mind, this is what happens to the poor, to the illiterate when they are deprived of the opportunities to be exposed to the joys of life due to depravity many times because their society does not allow their development and growth with corrupt practices of exploitation or they are forced into these circumstances for many years due to neglect by the government and by oppressive social structure. At times they are forced into this situation by the system of government, such as in communism.

Ethical values call for understanding, sensitivity and a will that completes action. Moreover, Stein writes, such values once fulfilled in action are "not merely to be carried out empathically as a single experience, but experienced as proceeding meaningfully from the total structure of the person" (Stein 1989, 112).

In Stein's account, attitudes and feelings are important. These can be a matter of pure "contagion," that is, persons can be "infected" by anger and rebellion, by love and hate of the people around them without the basis of a judgment of their own or the involvement of their personal "I."

\section{(c) Outsiders are power sources for the community}

Stein explains how human persons are all part of a larger physical word and are thus affected by a whole gamut of influences in the world. They are incorporated into the whole order of physical and psychic reality. Moreover, the human person can be "dependent on all kinds of circumstances that could be influenced by one another as well as by the states and the character of the living body" (Stein 1989, 109-110). Stein explains:

The individual with all his characteristics develops under the constant impression of such influences so that this person has such a nature because he was exposed to such and such influences. Under other circumstances, he would have developed 
differently. There is something empirically fortuitous in this "nature" (Stein 1989, 110).

To correlate what Stein said with Benedict's solidarity vision, this means that if human persons are formed and nurtured in a person-centred and communityoriented ethical environment as conceived by Benedict in $C V$, they could be influenced to grow up in an environment by outsiders in a way that works toward charity and truth promoting authentic and integral human development.

Stein says there could be individuals who stand outside of the community or even in contact with another community who can influence us. She cites the example of the influence of a professor on a sluggish and sleepy class. He gives an "invigorating jolt," not so much through the intellectual content of his lectures, but rather through the contagious vigour that emanates from him (Stein 2000, 206). Stein explains:

The two, professor and class, are not confronting each other alienly and independently like a subject and object. If they were, an if they were behaving sort of watchfully toward one another, then there would be no possibility at all for any overlap of causal connection. Rather the two form a unity of life within which the power of one benefits everyone in the collectivity (Stein 2000, 206).

Stein expands her example to two nations classing against each other: the hatred of one enkindles itself on the other. Strange as it may sound, write Stein, a community of life exists between the two hostile parties which, being two sharply defined personalities, do not become a fused unity. Such environmental factors from the outside have an impact on the life of the community members. Such an impact might be that the members of one community fear the other and somehow economic and political relations become strained altogether.

When we talk about the life of the past, we cannot separate our discussion from the historical truth that makes the life of a community. Historical personalities in this sense are sources of lifepower (as sources outside our present life). Recalling their significant contributions and life stories can help enliven us in situations wherein we need models of virtue and value. Through empathic comprehension of the foreign spiritual individual, the historical figure in question, who I come to read about, or know about from the narration of facts about his/her life, or learn about from his autobiography or from books he/she has written. 
That is why to build a community that rests on the value-filled life of historical figures, it is helpful and even necessary to inspire the members of society with the virtues of heroes, saints, past leaders who can serve as a model for the present generation to emulate their virtues and imitate them. Patriotism, for instance, is a virtue that can be emulated even if we may not be presently defending our country from invaders or colonizers. I may not have this experience at all in my lifetime perhaps, but I can feel patriotic, be patriotic, understand it, from a movie of the country's national hero or of a patriot who died for the country, preserving its culture.

It may happen also that one might find other's experiences and values as contrasting or conflicting with one's own. One might remain at the level of understanding them, but will not himself embrace their motivations for living. This is where, respect for other's freedom, values, and choices come in. This is where toleration as a value is required to preserve peace in a community.

\section{(d) The significance of social attitudes for the lifepower of community}

Stein explains that exchanges between individuals are affected for the most part in "social acts" I which one act is pointed at the, turned toward it. One is speaking and the other is understanding. And it belongs to the sense of these acts that the material content pronounced, and accordingly heard, is not only meant but also imparted and received. This reciprocal linkage enters into the experiential content too (Stein 2000, 210).

Stein writes that "there are attitudes of the person that matter directly to another person in her individual quality and affect her to the core: love, trust, gratitude, and so forth, and even that which we call 'faith' in a human being. On the other side stand distrust, aversion, hatred - in short, the whole set of 'rejecting' manners of behavior" (Stein 2000, 211). Attitude or Stellungnahme, literally means "stance-taking." Stein was discussing attitude as a kind of stance that involuntarily accompanies perception and that which is appropriate to whatever is being perceived. Attitudes emerge involuntarily and call for some decision (Stein 2000, 61). "... I give myself over to it, I allow it to take possession of me." But attitudes are subject to the contribution of the will (Stein 2000, 64). I can voluntarily take on one attitude at present and change to another the next moment.

Attitudes towards a person are sharply divided according to positivity and negativity and with this, the being of the person is affirmed or negated (Stein 2000, 211). Stein writes: 
Positivity and negativity don't exhaust the possibilities of all value-perceiving acts and attitudes toward values. Besides positive and negative attitudes, or course, an "indifferent" stance is possible that's neither "love" nor "hatred." Now these attitudes can become... a motive of an answering attitude, but at the same time can become effective as a causal factor... The love which I meet with strengthens and invigorates me and grants me the power for unexpected achievements. The distrust that I run into disables my creative power. Other people's attitudes encroach directly upon my inner life and control its course - unless I "lock myself up" against them which is possible here with all causal influences (Stein 2000, 211-212).

Stein further explains that "for every attitude is an attitude toward something and holds true for something objective that must be apprehended in some way or other. It is values that are inseparably bound with the being of a person, by which I take a positive or negative stance toward a person. The person stands before me as valued or disvalued. Stein explains:

I can find fault with a person whom I love or find merits in a person whom I hate. I can be fully aware of the disvalue that attaches to the loved person, but I'm not loving her as someone burdened with this disvalue. Rather, the disvalue of a property or of a single action - insofar as that disvalue on the whole is vividly felt - is eclipsed and cancelled by the value which inheres in the person's overall repertoire of being. And the pain over the felt disvalue doesn't diminish the love; it merely gives it a particular coloration (Stein 2000, 212).

For example, a married woman, on the whole, loves her husband, but is aware that he has a drinking problem, which is a disvalue. As she loves him, his disvalue - his drinking problem-is something she overlooks. She keeps on taking him back home when he comes home drunk, even if she is displeased with him. She makes excuses for him before the children. She gathers them to the television to watch a comedy as he is shouting invectives in the kitchen while drinking. Her loved cancels out his defect. ${ }^{11}$

We note that the relationship of value-perception and taking a stance on value is important. Stein explains:

The apprehending of a value and the attitude appropriate to it mutually require one another, and while the required attitude is 
not being experienced, the value isn't being apprehended vividly. So in a way it's correct to say that love is based upon the apprehended value of the beloved person, but on the other hand, the worth of a person is fully and completely accessibly only to the lover (Stein 2000, 213).

Thus, in the example given about the married woman mother loving her alcoholic husband in spite of his difficult drinking problem, we might say, the woman loves her husband, values him as her child, which does not diminish even when she sees him intoxicated and perhaps somewhat violent. The woman finds ways to make her children understanding, forgiving, patient, and hopeful that their father would change. What Stein explains as follow helps us appreciate the virtues of such a mother and helps us emulate her attitudes.

Inasmuch as values "induce" attitudes in us whose contents convey new propellant powers to our mental life, we have regarded them themselves as "life-contributing." That goes for all values without distinction, material and personal alike, regardless of whether they're realized or not. Personal value attaches to the qualitative substance of the person, not to her existence (Stein 2000, 213).

In other words, personal values and the attitudes that go with make us better persons. Whether the alcoholic man stops drinking or not, whether the children forgive him, excuse him or not, the woman who foster these values is substantially a better person for her patience, cheerfulness, and charity. Eventually, in the story, the children become open to forgiving their father and accepting him as he is. Their mother's strength enables them to do this. Such attitudes are meaningful for life in a community (in my example, the family). We read from Stein:

[For one,] the solidarity of individuals, which becomes visible in the influences of the attitudes of one upon the life of the others, is formative community in the highest degree. Where the individuals are "open" to one another, where the attitudes of one don't bounce off of the other but rather penetrate him and deploy their efficacy, there a communal life subsists, there the two are members of one whole; and without such a reciprocal relationship community isn't possible (Stein 2000, 214). 


\section{Empathy and Solidarity}

Solidarity, like all values, can be understood better, and it is precisely by writing about it in $C V$ that Pope Benedict informs about the possibility of being one community in striving for authentic and integral human development. Knowledge of a value is always the starting point for wanting it and willing it. I see Pope Benedict's attempt at instructing us in his social encyclical $C V$ about ethical values helpful to make us reflect on solidarity as a value we should strive for and feel strongly for. As Stein writes:

Not only the knowledge we have, but, perhaps to a still greater extent, the knowledge not yet realized is felt as a value. This feeling of value is the source of all cognitive striving and "what is at bottom" of all cognitive willing. An object proffers itself to me as dark, veiled, unclear. It stands there as something which demands exposure and clarification. The clarifying and unveiling with their result in clear and plain knowledge stand before me as a penetratingly felt value and drag me irresistibly into them.

The cognitive process itself is an activity, a deed. I not only feel the value of the cognition to be realised and joy in the realised one, but in the realising itself I also feel that strength and power we found in other willing and action (Stein 1989, 108).

Since the experience of value is basic to our own value, at the same time as new values are acquired by empathy, our own unfamiliar values become visible. When we empathically run into ranges of values closed to us, we become conscious of our own deficiency or disvalue. Every comprehension of different persons can become the basis of an understanding of value. Since, in the act of preference or disregard, values often come to givenness that remain unnoticed in themselves, we learn to assess ourselves correctly now and then. We learn to see that we experience ourselves as having more or less value in comparison to others.

By empathy with differently composed personal structures we become clear on what we are not, what we are more or less than others. Thus, together with self knowledge, we also have an important aid to self evaluation (Stein 1989, 116).

We can evaluate what our motivations are, whether they are selfish and selfcentred. We can examine ourselves on our intention and whether these help the community to which we belong. We can assess whether our desires, volitions, and actions somehow contribute to the development of humanity as a whole. 
Thus, if several wills then coincide in the same motivation, I think solidarity can be achieved as a community goal, as it is not impossibility. For instance, in $C V$, Pope Benedict speaks about working toward achieving integral human development. "The development of individuals and peoples requires new eyes and a new heart capable of rising above a materialistic vision of human events, capable of glimpsing in development the beyond" that technology cannot provide" (Benedict XVI 2009, 77). I think the "will to solidarity" is something that people can be made to feel through the inspiration of national leaders who could primarily give people the motivations for solidarity. Parents and teachers are also in such a position to make children and students "feel" the need for uniting to achieve this value. Intellectual, researchers, writers, mass media specialists can also contribute to this end in their varied spheres of influence. After all:

"Willing," writes Stein, "is essential motivated by a feeling.
Therefore an umotivated willing is an impossibility. There is no
conceivable subject with a nature to want something which does
not appear to it as valuable. Willing by its meaning (that posts
something to be realized) is directed toward what is possible,
i.e., realizable (Stein 1989,97).

To my mind, solidarity in this globalised world is achievable. Benedict XVI's proposal to experience and steer to a "globalization of humanity in relational terms, in terms of communion and the sharing...." (Benedict XVI 2009, 42) intertwined with Stein's phenomenological conception of community can be accomplished. I hope that this interconnection of Stein's phenomenological notion of community with Benedict's vision of solidarity can be coursed into a reality of achievable terms.

\section{The Human Person as Relational}

I can experience the sense of the communal because of my common belonging to the human family and my participating in human (personal) being. And I can understand and participate in the communal experience because I experience the communal as communal and appreciate that it is marked by the uniqueness of many individual persons who contribute to the very making and becoming of such a communal experience. Ultimately, there is a fundamental relation that exists among the individuals of the community. Each is required in order to define the other.

To fail to appreciate the human person as a being in relation leads to "retarding or even obstructing authentic human development." ${ }^{12}$ A denial altogether of this 
truth about human nature results in the poverty of isolation with human beings absorbed in themselves. Such an attitude leads to inequality, exploitation and oppression, as well as greed and selfishness. To put in Teilhard de Chardin's biological approach: "The human monad can only be absolutely itself by ceasing to be alone"13 (de Chardin in Ratzinger 2004a, 236-237). There is no individual who is completely separated from other individuals. For one, we are born into the world through a human being and go through life processes (education, barter and trade, communication, travel) also with other human beings, oftentimes with dependence upon them for our needs to be met.

For if this dependence is first of all a physical one (and even in this sphere it extends from parentage down to the manifold interactions of mutual daily care), it means for him who is spirit in a body and as body, that the spirit, too-in short, the one, whole man is deeply marked by his belonging to the whole of mankind (Ratzinger 2004a, 246).

Ratzinger stresses that man is a being that can only "be" by virtue of others. Or, put it in the words of the great Tubingen theologian Mohler: "Man, as a being set entirely in a context of relationship, cannot come to himself through himself, although he cannot do it without himself either." ${ }^{14}$

Just as self-love is not the primordial form of love but at most the derivative of it, just as one has only arrived at the specific nature of love when one has grasped it as a relation, that is, something coming from one another, so, too, human knowledge is only reality when it is being known, being brought to knowledge, and thus again, "from another." Ratzinger writes that the real man does not come into it at all if he only plumbs the loneliness of the "I," of self-knowledge, for then he excludes in advance the point of departure of his ability to come to himself and thus his most specific characteristic. Only from man's being known can his knowledge and he himself be understood (Ratzinger 2004a, 47).

The possibility of solidarity in the world comes from the fact the human being is not an atomised individual. To understand Ratzinger's point, we need to consider atoms, which are the basic unit of matter, move about in an infinite void and repel other atoms when they collide. ${ }^{15}$ But man, unlike the atom, is not made to repel other men. He belongs to a whole and is himself only when he is fitted into the whole: into mankind, into history, into the cosmos, as is right and proper for a being who is "spirit in body" (Ratzinger 2004a, 243). Ratzinger explains:

The principle of "body" and "corporality" that governs man elucidates this. On one hand, the body separates men from one another, makes them impenetrable to each other. As a space- 
filling and sharply defined shape, the body makes it impossible for one to be completely in the other; it erects a dividing line that signifies distance and limit; it keeps us at a distance with one another and is to that extent, a dissociation principle. But at the same time existence in a corporal form implies interdependence. For if pure spirit can be thought of as existing strictly for itself, corporality implies descent from one another; human beings depend in a very real and at the same time very complex sense on one another for their lives (Ratzinger 2004a, 245-246).

This interdependence does not end in symbiosis, where organisms associate with other organisms, living on each other. Human interdependence goes beyond physical survival and transcends the biological order. Although necessarily involving physical connection through the body, human corporality extends to the creation of history, of culture, and of building a human community together. As Ratzinger writes:

Being a man means being a fellowman in every aspect, not just in the present moment, but in such a way that every man also contains the past and future of mankind, which already does prove... to be one single "Adam"16 (Ratzinger 2004a, 247).

Being a fellowman runs backwards and forwards through time, connecting us not only with the other people who are alive at this moment but also with all past and future generations. There is no such a thing as the mere individual. The manmonad of the Renaissance, the pure "cogito ergo sum" being does not exist, writes Ratzinger (Ratzinger 2004a, 247). Humanity belongs to man only in the web of history that impinges on the individual; and the individual for his part lives in life on the collective pattern in which he is already previously included and that forms the scene of his self-realisation (Ratzinger 2004a, 247-248). A framework of the already existing whole of human life has stamped his existence and molds him (Ratzinger 2004a, 248). His language, speech, and forms of communication, for instance have been given to him in history. We notice that the relations of love, communication, and knowledge are all part of being human. Everyone lives in a web that is part of his very existence (Ratzinger 2004a, 249). It is a network that stretches out to the whole of humankind and to the infinite.

To turn against the truth of man's relational nature is a "rebellion against being human in itself" that "leads people — as Sartre percipiently observed — into a selfcontradictory existence that we call hell" ${ }^{17}$ (Ratzinger 2013, 160). When the human person is alone and thinks him/herself to be self-sufficient or merely an insignificant and ephemeral fact, a stranger in a random universe (Benedict XVI 
2009, 29), he detaches himself from the joy and reality of being surrounded by others and living in social relations. He deprives himself of the opportunity to learn from others, to give and share, and to be a recipient as well of what others have to give.

In this regard, it helps to note that "man is not a lost atom in the universe: he is God's creature"18 (Benedict XVI 2009, 29). Moreover, "it is not by isolation that man establishes his worth, but by placing himself in relation with others and with God" (Benedict XVI 2009, 53). This thinking, as Benedict XVI puts it, can be useful in public discussions concerning the economy and other aspects of social life.

\section{Conclusion}

"Development depends on seeing ourselves as a human family, not as a group of subjects who happen to live side by side" (Benedict XVI 2009, 53). Persons do not live in isolation from each other and are not separate entities deserving more of economic sources at the expense of others. Persons are not disconnected beings who should only fend for themselves without mindfulness of others' needs in this world. The economy cannot be disjointed from the truth about the human being and if conjoined with charity or love, the economy achieves authentic and integral human development. We need to feel for others. We can uplift their spirits when they are low by invigorating them with our own cheerful spirits. We can help when they are in need. Ultimately, there is a fundamental relation that exists among all of us. We have one Father, God. "We," though we are many "I's," are just one human race, one community, one family. Each is required to complete the other. To live within the selfishness of our own confined little worlds would be to limit our growth and stagnate our development. The world is a more vast expanse than our small and individualistic concerns. The person who does not "globalise" will be left behind.

Stein's and Benedict's reflections on community and solidarity constitute a call that asks for a response. We need to put an end to an attitude that insists, "this is mine" and "that is yours." After all, the world is just one globe. It is your world and mine, together. It is our world.

\section{Notes}

1. Edith Stein was born in Breslau, Germany in 1891 to a Jewish family. Her initial studies were in psychology in a period when psychology was just beginning as a university discipline. Later she turned to philosophy after reading Edmund Husserl's Logical Investigations. At that time, phenomenology was just developing as a new interest among philosophy specialists. 
The term "phenomenology" was adopted to describe a method to study the different ways in which things appear to consciousness. One single reality can present itself in different ways. For example, my thesis defence day can appear to me as a live experience while it is happening, as a frightening expectation while I am preparing for it, or as a fulfilling achievement after the event. Any knowable object appears to consciousness in modes that are appropriate in themselves; and we have to comprehend these modes if we are to appraise the reliability of our knowledge of that object.

Edith Stein studied directly under the "father" of phenomenology, as people referred to Husserl. Stein obtained her doctorate summa cum laude from the University of Freiburg in 1916, for her dissertation On the Problem of Empathy. She is significant for three innovations in the history of philosophy: the reconciliation of Thomism with phenomenology, the integration of psychology and philosophy in the particular study of empathy, and the consideration of "woman" as a fundamental category for philosophical research. Although considered to be one of the few women who belonged to the German philosophical group of her time, Edith Stein was never given full credit then for her contribution to philosophy because of her gender and race. She died in Auschwitz in 1942.

2. Individual and Community is the second of two treatises in Edith Stein's Philosophy of Psychology and the Humanities (2000).

3. Stein's use of the term "ontic" precedes Heidegger's ontic/ontological distinction. "Ontic" simply refers to the essential being of the community. In phenomenological terms, it refers to the ideal being of the object of consciousness" (Calcagno, 138).

4. Benedict XVI is papal name of Joseph Ratzinger. The 265th Bishop of Rome is a German theologian who was prefect of the Congregation for the Doctrine of the Faith and dean of the College of Cardinals of the Vatican before he was elected pope. In 2009, Pope Benedict issued his third encyclical Caritas in Veritate (henceforth $C V$ ) where he examines the relationship between charity and truth in the light of 2009 issues: the economic and financial crisis, the environment, and how these relate to a Christian vision of the world. The professed central theme of the encyclical - integral human development in charity and truth - is of universal concern and relevance according to scholars who have examined the work carefully.

5. There are four Greek words for love: agápe, éros, philia, and storgē. God's love has been expressed by Agápe which means love in a "spiritual" sense. The term s'agapo, which means "I love you" in Ancient Greek, often refers to a general affection or deeper sense of "true unconditional love" rather than the attraction suggested by "eros." This love is selfless; it gives and expects nothing in return ( $c f$. The Four Loves by Lewis 1988).

6. Aquinas, Summa Theologiae, I-II, 26, 4, corp. art."Newadvent.org (accessed 30 October 2010).

7. Individual and Community is published as a second treatise in Philosophy of Psychology and the Humanities, 1922.

8. The term "subject" in phenomenology refers to the owner of consciousness and the content of conscious experience consisting of perception, emotion, judgment vs. object, that to which consciousness is directed. 
9. The German Geist has no exact translation in English, but since it is one of the key terms in Edith Stein's discussion of community, we need to understand how she meant and used it. The sense of Geist is that of the creative human spirit that is the subject matter of the humanities. Among the possible English translations are "mind" and "spirit." The Stein specialists vary in the meaning and usage of Geist. I will adopt Geist to mean "spirit" as spirit explains the vigour and life-force that Stein attaches to community.

10. Communion and Stewardship: Human Persons Created in the Image of God (2004), International Theological Commission with Augustine Di Noia, O. P., Jean-Louis Bruguès, Anton Strukelj, Tanios Bou Mansour, O. L. M., Adolpe Gesché, Willem Jacobus Eijk, Fadel Sidarouss, S. J., and Shun ichi Takayanagi, S. J. Cardinal Ratzinger was President of the Commission.

11. A true story set into film, the movie Prize Winner of Defiance, Ohio (2005), is a biographical story written by Terry Ryan, the daughter of the mother I mention in the example above.

12. $\quad C V$ supra note 55 Cf. Encyclical Letter, Sollicitudo Rei Socialis, 28.

13. Ratzinger thinks de Chardin's biological approach is not entirely unobjectionable tendency and is useful for elucidating the relational character of human beings (de Chardin quoted by Tresmontant Introduction a le pensee de Teilhard de Chardin (Paris, 1956), p. 68 in Ratzinger 2004a, 236-237).

14. Geiselmann summarising the ideas of Mohler in the Theologische Quartalschrift, 1830, pp. 582f; J. R. Geiselmann, Die Heilige Schrift und die Traditition (Freiburg, 1962), p. 56 in Ratzinger's Introduction to Christianity, 246).

15. "Atomist Doctrine." Democritus. Stanford Encyclopedia, 2010. http://plato.stanford.edu/entries/democritus/\#2 (accessed 14 June 2014).

16. The Hebrew adam was originally used as a common rather than a proper name. Adam refers to the first man and the father of the human race (http://www.newadvent.org/cathen/01129a.htm).

17. Joseph Ratzinger in Communio, Vol. 2: Anthropology and Culture (Ressourcement: Retrieval and Renewal in Catholic Thought), Pope Benedict XVI, David L. Schindler (Editor), Nicholas J. Healy (Editor), Wm. B. Eerdmans Publishing Company, 2013, 160.

18. Supra note 70 in CV. Cf. Benedict XVI, Homily at Mass, Islinger Feld, Regensburg, 12 September 2006.

\section{Bibliography}

Baseheart, M. C. 1992. Edith Stein's philosophy of community. The Personalist Forum 8(1): 163-173.

1996. Person in the world. Amsterdam: Kluwer Academic Publishers.

Bello, A. A. 2006. The spiritual life and its degrees according to Edith Stein. Listening Journal of Religion and Culture 41(3): 152-171. . 2007. The study of the soul between psychology and phenomenology at Edith Stein. Cultura 4(2): 90-108.

Benedict XVI, Pope. 2009. Caritas in Veritate: On integral human development in charity and truth. Rome: Libreria Editrice Vaticana. 
Breen, J. M. 2010. Love, truth and the economy: A reflection on Benedict XVI's Caritas in Veritate. Harvard Journal of Law and Public Policy 33: 987-1028.

Calcagno, A. 2007. The philosophy of Edith Stein. Pittsburgh, PA: Duquesne University Press.

Compendium of the catholic church. 2004. Rome: Libreria Editrice Vaticana.

Husserl, E. 1960. Cartesian meditations: An introduction to phenomenology. Netherlands: Martinus Nijhoff.

John XXIII, Pope. 1961. Mater et magistra: On christianity and social progress. Rome: Libreria Editrice Vaticana.

John Paul II, Pope. 1987. Sollicitudo rei socialis: On social concern. Rome: Libreria Editrice Vaticana.

Karlowicz, D. 2002. "Solidarity" as church. Thinking in Values 1: 143-158.

Lebech, M. 2004. Study guide to Edith Stein's philosophy of psychology and the humanities. Ireland: National University of Ireland. 2006. Edith Stein's philosophy of education in the structure of the human person. Religion, Education and the Arts of the Philosophy of Education 5: 55-70.

Leo XIII, Pope. 1891. Rerum novarum: On the condition of labor. Rome: Libreria Editrice Vaticana.

Paul VI, Pope. 1967. Populorum progressio: On the development of peoples. Rome: Libreria Editrice Vaticana.

Pius XI, Pope. 1931. Quadragesimo anno: On reconstructing the social order. Rome: Libreria Editrice Vaticana.

Ratzinger, J. 2004a. Introduction to Christianity. San Francisco: Ignatius Press. 2004b. Communion and stewardship: Human persons created in the image of God. Rome: Libreria Editrice Vaticana.

2013. Anthropology and culture. Michigan: Wm. B. Eerdmans Publishing Company.

Salij, J. 2000. On solidarity somewhat theologically. Thinking in Values 1: 85-95.

Sawicki, M. 1997. Body text and science the literacy of investigative practices and the phenomenology of Edith Stein. Netherlands: Kluwer Academic Publishers. . 1998. Personal connections: The phenomenology of Edith Stein. Presented at St. John's University, New York, 15 October. http://www.nd.edu/ colldev/subjects/ catholic/personalconn.html (accessed 23 January 2014). . 2001. The humane community: Husserl versus Stein. Washington DC: The Council for Research in Values and Philosophy.

Sharkey, S. B. 2003. Edith Stein: Outstanding thinkers. New York: Continuum. 2010. Thine own self: Individuality in Edith Stein's later writings. Washington DC: The Catholic University of America Press.

Sokolowski, R. 2001. Introduction to phenomenology. Cambridge: Cambridge University Press.

Stein, E. 1986. Life in a Jewish family. Washington DC: ICS Publications. 1989. On the problem of empathy. Washington DC: ICS Publications. 1994. Self-portrait in letters, 1916-1942. Washington D.C.: ICS Publications. 1996. Essays on woman. Washington DC: ICS Publications. . 2000. Philosophy of psychology and the humanities. Washington DC: ICS Publications 
. 2007. An investigation concerning the state, trans. Sawicki, M. Washington DC: ICS Publications.

Quito, E. 2001. Phenomenology: Edmund Husserl and Edith Stein. Philippines: De La Salle Press.

Van de Berg, R. 2000. Community in the thought of Edith Stein. New York: Catholic University of America.

Von Hildebrand, D. 1992. Man and woman. New York: Sophia Institute Press.

Workowski, A. 2006. The solidarity community: A phenomenological analysis. Thinking in Values 1: 107-142. 